\title{
A Survey on Area, Production and Productivity of Groundnut Crop in India
}

\author{
Dr B. Madhusudhana \\ Department of Economics, S S B N Degree \& PG College, Anantapuram - 515001, A.P
}

\begin{abstract}
This survey has been carried out to discuss the ground nut area, production and productivity in India, Andhra Pradesh State and Anantapuram district. It analyzed the area, production and productivity of groundnut crop at national level, state level and district level during 1996-2000 to 2001-2008. The present comparative analysis of groundnut production in A.P and in Anantapuram district during 1996-2000 to 20012006. The groundnut crop area, production and productivity at national level, state level and Anantapuram district level of during 1996-2000 to 2001-2006 were collected and presented graphically. Based on the results collected some conclusions are made about the improving the production of groundnut crop.
\end{abstract}

Keywords: Area, Groundnut, Production, Productivity, Rain field

\section{Introduction}

India is one of the largest producers of oilseeds in the world and occupies an important position in the Indian agricultural economy. It is estimated that nine oilseeds namely groundnut, rapeseed-mustard, soybean, sunflower, safflower, sesame, Niger, castor and linseed, accounted for an area of 23.44 million hectares with the production of 25.14 million tonnes [1]. Groundnut is called as the 'King' of oilseeds. It is one of the most important food and cash crops of our country. While being a valuable source of all the nutrients, it is a lowpriced commodity. Groundnut is also called as wonder nut and poor men's cashew nut. Groundnut is one of the most important cash crops of our country. It is a low-priced commodity but a valuable source of all the nutrients.

Groundnut is grown on 26.4 million ha worldwide with a total production of 37.1 million metric $t$ and an average productivity of 1.4 metric t/ha [2]. Over 100 countries worldwide grow groundnut. Developing countries constitute $97 \%$ of the global area and $94 \%$ of the global production of this crop. The production of groundnut is concentrated in Asia and Africa (56\% and $40 \%$ of the global area and $68 \%$ and $25 \%$ of the global production, respectively).

\section{Area and Production of Groundnut Crop}

The major groundnut producing countries in the world are India, China, Nigeria, Senegal, Sudan, Burma and the United States of America. Out of the total area of 18.9 million hectares and the total production of 17.8 million tonnes in the world, these countries account for about 69 percent of the area and 70 percent of the production. India occupies the first place, both in regard to the area and the production in the world. About 7.5 million hectares are put under it annually and the production is about six million tonnes. Seventy percent of the area and seventy five percent of the production has been concentrated in the four states of Gujarat, Andhra Pradesh, Tamil Nadu and Karnataka. Andhra Pradesh, Karnataka, Tamil Nadu and Orissa have irrigated areas primarily during the rabi season. The irrigated areas form about six percent of the groundnut area in India. In these states groundnut production is mainly depends on rainfall. Patel et al examined the price behaviour of groundnut in Gujarat [3].

\section{Climate and Soil}

Groundnut is grown throughout the tropics and its cultivation is extended to the subtropical countries lying between $45^{\circ}$ North and $35^{\circ}$ South and up to an altitude of 1,000 meters. The crop can be grown successfully in places receiving a minimum rainfall of $500 \mathrm{~mm}$ and a maximum rainfall of $1250 \mathrm{~mm}$. The rainfall should be distributed well during the flowering and pegging of the crop. The total amount of rainfall required for presowing operations (preparatory) is $100 \mathrm{~mm}$, for sowing it is $150 \mathrm{~mm}$ and for flowering and pod development an evenly distributed rainfall of $400-500 \mathrm{~mm}$ is required. The groundnut crop, however, cannot stand frost, long and severe drought or water stagnation.

Groundnut is grown on a variety of soil types. However, the crop does best on sandy loam and loamy soil and in black soils with good drainage. Heavy and stiff clays are unsuitable for groundnut cultivation as the pod development is hampered in these soils. 


\section{Seasons for Groundnut Cultivation}

Groundnut is raised mostly as a rain fed Kharif crop, being sown from May to June, depending on the monsoon rains. In some areas, or where the monsoon is delayed, it is sown as late August or early September.

As an irrigated crop it is grown to a limited extent between January and March and between May and July. For a Kharif crop, with the onset of rains in May and June, the field is given two ploughings and soil is pulverized well to obtain a good tilth. The third ploughing may be given for cultivation. Pant, D.C et al examined the economic aspects of groundnut processing in Southern Rajasthan [4].

\section{Varieties of Groundnut}

The varieties under cultivation fall into three groups in respect of the habit of growth, namely bunch (Spanish), semi-spreading and spreading. In the bunch group, the plants grow erect, possess light-green foliage, produce pods in clusters at the base of the plant and have round, plump non-dormant seeds, with light-rose test. In the case of the semi-spreading and spreading varieties, the branches trail either partially or completely on the surface of the soil, produce pods all along them, possess dark-green foliage and have oblong, dormant brownish seeds. The semi-spreading and spreading types are usually heavier yielding and later maturing than the bunch varieties. Margaret et al pointed out that though the condition of the poor farmer could be improved by way of raising the quality and quantity of the output, yet the farmer might not reap benefits owing to the exploitative practices of manufacturers and financiers and the wasteful marketing system[5].

\section{Results And Discussion}

Out of the nine-oilseed crops grown in India, groundnut accounts for about 45 percent of the total cropped area under oilseeds and 55 percent of the total area under oilseeds production. As such, the edible oil economy in India is primarily depending on groundnut production. Though India leads the world both in area and production of groundnut, the country ranks eight in productivity, which is lower by about $100 \mathrm{Kg}$. than the world average. The low yield levels are attributed to cultivation of the crop mostly in rain fed areas and in marginal lands with low inputs, low technology, poor plant population, inadequate fertilization and lack of plant protection. Another factor is inefficient post-harvest technology; all these factors have jointly contributed to low and unstable yields of groundnut crop in India.

Groundnut is an important protein supplement for cattle and poultry rations. It is also consumed as a confectionery product. The cake can be used for manufacturing artificial fibre. The haulms are fed to livestock. Groundnut shell is used as fuel for manufacturing coarse boards, cork substitutes. Groundnut is also valued as a rotation crop. Being a legume with root nodules, it can synthesize with atmospheric nitrogen and thereby improve soil fertility.

\section{Area, Production and Productivity of Groundnut in India}

In India, 6,853 thousand hectares of area is under cultivation and produces 7867 thousand tonnes of the groundnut during 2005-2006 as shown in table3.2. Its production during 1996-97 was 8643 thousand tons with the yield of $1138 \mathrm{kgs}$ per hectare in India. However, the area under groundnut was declined from 7596 thousand tonnes in 1996-97 to 5953 thousand tonnes in 2002-03. During the next three years i.e., from 2003-04 to 2007-08, the area under groundnut was increased from 5998 thousand tonnes to 6853 thousand tonnes. The reason for the declining trend of groundnut area is mainly change of cropping pattern and low rainfall in the southern states during the last few years. There were fluctuations in the production of groundnut in India during the decade 1996-97 to 2005-06. During 2002-03 the area, production and productivity of groundnut was low due to low rainfall in Gujarat and Andhra Pradesh.

Table 1: Area, Production and Productivity of Groundnut Crop in India during 1996-2008

\begin{tabular}{|c|c|c|c|}
\hline Year & $\begin{array}{c}\text { Area } \\
\text { (000'hectaes) }\end{array}$ & $\begin{array}{c}\text { Production } \\
\text { (000'tonnes) }\end{array}$ & $\begin{array}{c}\text { Productivity } \\
\text { Per hectare } \\
\text { (in kgs) }\end{array}$ \\
\hline $1996-97$ & 7596 & 8643 & 1138 \\
\hline $1997-98$ & 7088 & 7372 & 1040 \\
\hline $1998-99$ & 7396 & 8982 & 1214 \\
\hline $1999-00$ & 6867 & 5258 & 766 \\
\hline $2000-01$ & 6732 & 6408 & 952 \\
\hline $2001-02$ & 6238 & 6865 & 1100 \\
\hline $2002-03$ & 5953 & 4663 & 1353 \\
\hline $2003-04$ & 5998 & 8127 & 992 \\
\hline $2004-05$ & 6827 & 6774 & 1148 \\
\hline $2005-06$ & 6853 & 7867 & 1126 \\
\hline $2006-07$ & 6942 & 7815 & 1188 \\
\hline $2007-08$ & 6917 & 8216 & $\mathbf{1 0 6 6 . 8 3 3}$ \\
\hline Annual Average & $\mathbf{6 7 8 3 . 9 1 7}$ & $\mathbf{7 2 4 9 . 1 6 7}$ & \\
\hline
\end{tabular}

Source: Directorate of Economics and Statistics India, Various issues 2009. 


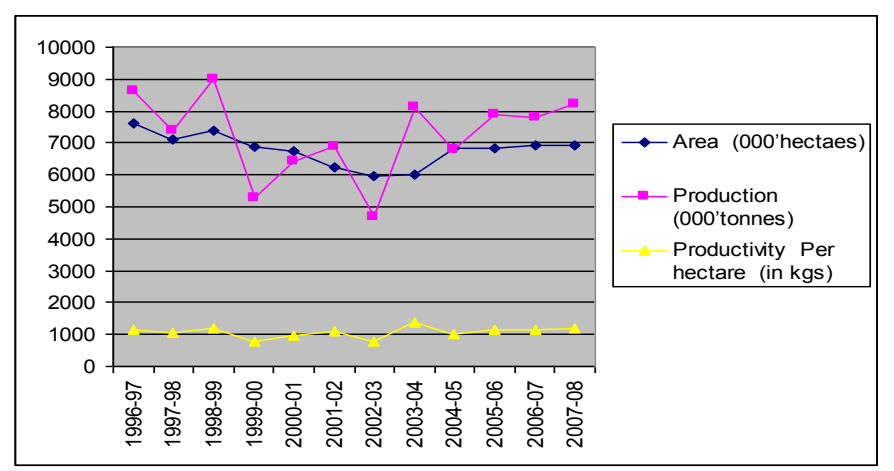

Fig. 1: Area, Production and Productivity of Groundnut Crop in India (1996-08)

The annual average area, production and productivity of groundnut during 1996-97 to 2005-06 was 6754 thousand hectares, 7095 thousand tons of production and $1048 \mathrm{kgs}$ per hectare respectively as shown in table 1. The area, production and productivity of groundnut in India during 1996-97 to 2005-06 are presented in Fig. 1.

\section{Area, Production and Productivity of Groundnut in Major Groundnut Growing States of India}

The state-wise break up of area production and productivity of groundnut is presented in table 2. It may be noted that Andhra Pradesh, Gujarat, Karnataka and Tamil Nadu occupied the top four positions in area cultivated. Gujarat tops with 2000 thousand hectares followed by Andhra Pradesh 1841 thousand hectors, Karnataka 967 thousand hectors and Tamil Nadu 615 thousand hectors. But there is a slight change in the order as far as production is concerned. Gujarat tops with 27.87 percent of total production followed by Andhra Pradesh 24.19 percent, Tamil Nadu 14.84 Percent and Karnataka 1095 percent. Though other states like Maharashtra, Rajasthan, Orissa, Madhya Pradesh, Uttar Pradesh and West Bengal are the important groundnut producing states.

Table 2: Area, Production and Yield of Groundnut Crop in Major Groundnut Growing States in India during 2005-2006

\begin{tabular}{|c|l|c|c|c|}
\hline S. No & \multicolumn{1}{|c|}{ State } & $\begin{array}{c}\text { Area } \\
(\mathbf{0 0 0} \text { 'hectares) }\end{array}$ & $\begin{array}{c}\text { Production } \\
\mathbf{( 0 0 0 ' t o n n e s )}\end{array}$ & $\begin{array}{c}\text { Yield per hectare } \\
\text { (in kgs) }\end{array}$ \\
\hline 1 & Andhra Pradesh & 1841 & 1639 & 890 \\
\hline 2 & Gujarat & 2000 & 1886 & 943 \\
\hline 3 & Karnataka & 969 & 742 & 766 \\
\hline 4 & Maharastra & 447 & 502 & 1123 \\
\hline 5 & Madhya Pradesh & 209 & 242 & 1157 \\
\hline 6 & Tamil Nadu & 615 & 1005 & 1634 \\
\hline 7 & Orissa & 231 & 351 & 1519 \\
\hline 8 & Rajasthan & 287 & 446 & 1554 \\
\hline 9 & West Bengal & 046 & 071 & 1543 \\
\hline 10 & Uttar Pradesh & 085 & 069 & $\mathbf{6 7 7 4}$ \\
\hline
\end{tabular}

Source: Directorate of Economics and Statistics, India, Various issues.

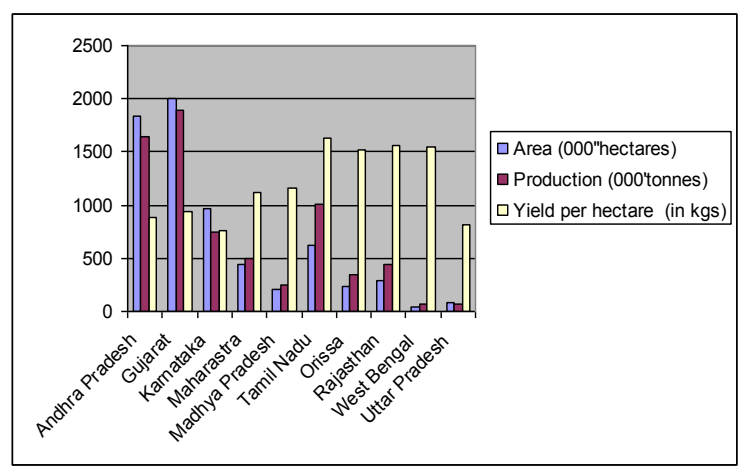

Fig. 2: Area, Production and Yield of Groundnut Crop in Major Groundnut Growing States in India during 2005-2006 
The production of groundnut per hectare is high in Tamil Nadu with $1634 \mathrm{kgs}$ per hectare, but it was in third place in total groundnut production during 2005-06. The yield per hectare is low in major groundnut growing states of Andhra Pradesh and Gujarat. The yield per hectare is very low in Karnataka (766 kgs per hectare) comparatively with other states. The area, production and productivity of groundnut in major groundnut growing states of India are presented in diagram .2.

\section{Area, Production and Productivity of Groundnut in A.P}

The area, production and productivity of groundnut crop in Andhra Pradesh during 1996-97 to 200809is presented in table 3. The area under groundnut crop in Andhra Pradesh was fluctuated between 14,69,624 hectares in 2002-2003 and 21,98,324 hectares in 1996-97.It is observed that the area under groundnut was declined in Andhra Pradesh from 21,98,324 hectares to 14,69,624 hectares during 1996-97 to 2002-03. The reason for this declining trend in area under groundnut was mainly inadequate and uneven rainfall in Rayalaseema region and change of cropping pattern in recent years in irrigated as well as un irrigated areas in all over the state.

Table 3: Area, Production and Yield of Groundnut Crop in Andhra Pradesh during 1996-06

\begin{tabular}{|c|c|c|c|}
\hline Year & $\begin{array}{c}\text { Area } \\
\text { (in hectares) }\end{array}$ & $\begin{array}{c}\text { Production } \\
\text { (in tonnes) }\end{array}$ & $\begin{array}{c}\text { Yield Per hectare } \\
\text { (in kgs) }\end{array}$ \\
\hline $1996-97$ & 2198324 & 20,44971 & 930 \\
\hline $1997-98$ & 1834032 & 1155930 & 630 \\
\hline $1998-99$ & 1991919 & 2155067 & 6061 \\
\hline $1999-00$ & 1795117 & 1089246 & 1143 \\
\hline $2000-01$ & 1873817 & 2142953 & 739 \\
\hline $2001-02$ & 1691118 & 1250233 & 558 \\
\hline $2002-03$ & 1469624 & 820654 & 660 \\
\hline $2003-04$ & 1493259 & 985813 & 890 \\
\hline $2004-05$ & 1841133 & 1639241 & 728 \\
\hline $2005-06$ & 1875544 & 1365817 & 557 \\
\hline $2006-07$ & 1334232 & 742637 & 1450 \\
\hline $2007-08$ & 1795306 & 2602847 & 510 \\
\hline $2008-09$ & 1766354 & 973264 & 1459129 \\
\hline
\end{tabular}

Source: Directorate of Economics and Statistics India, Various issues.

But during the next three years, the area under groundnut was increased from 14,93,259 hectares in 2003-04 to 18,75,544 hectares in 2005-2006. The production of groundnut crop was also fluctuated from year to year during the decade under study. In three out of ten years under study the production of groundnut varied from $7,42,637$ tons to $26,02,847$ tons. The productivity of groundnut was significant in two out of ten years under study (1,081 kgs in 1998-99 and 1,143 kgs in 2000-01).

The reason for this may be due to good monsoons during these two years under reference. The productivity is very low with a variation of $551 \mathrm{kgs}$ per hectare to $738 \mathrm{kgs}$ per hectare in eight out of 13 years under reference. The area, production and productivity of groundnut crop in Andhra Pradesh during 1996-97 to 2005-2009 is diagrammatically presented in Fig.3.

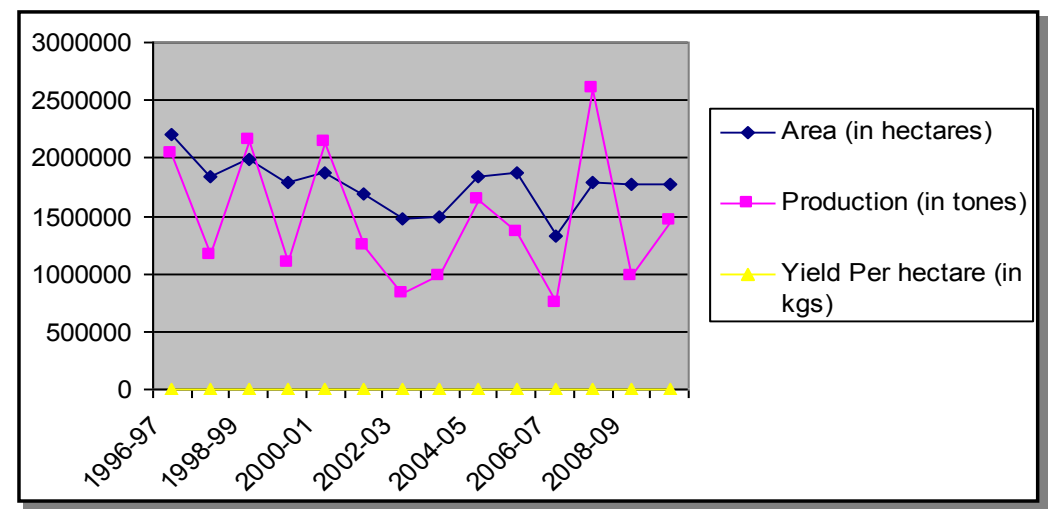

Fig. 3: Area, Production and Yield of Groundnut Crop in Andhra Pradesh during 1996-09 


\section{Area and Production of Groundnut Crop in Anantapuram District}

It can be observed from the table 4 that the area and production of groundnut in Anantapuram district are showing a steady growth with increasing trend. However, the average yield per hectare has almost remained different variations during the period under study. The total area under groundnut increased from 7,59,419 hectares in 1996-97 to 8,99,035 hectares in 2005-06 recording an increase of 18.38 percent. Correspondingly, the production has decreased form 5,55,251 tons in 1996-97 to 3,91,965 tons in 2005-06 registering a decrease of 29 percent and again declined to 1,00,012 tons. The production was increased from 9,03,614 tons in 1998-99 recording an increase of 62.74 percent and also production increased to 9,08,795 tons in 2000-01 recording an increase of 63.67 percent and again it increased to 11,30,126 tons in 2007-08.

Table 4: Area, Production and Yield of Groundnut Crop in Anantapuram District during 1996-2009

\begin{tabular}{|c|c|c|c|}
\hline \multirow{2}{*}{$\begin{array}{l}\text { Year } \\
1996-97\end{array}$} & Area (in hectares) & $\begin{array}{c}\text { Production } \\
\text { (in tons) }\end{array}$ & $\begin{array}{c}\text { Yield } \\
\text { per hectare } \\
\text { (in kgs) }\end{array}$ \\
\hline $1997-98$ & $7,59,419$ & $5,55,251$ & 731 \\
\hline $1998-99$ & $6,71,047$ & $2,50,175$ & 372 \\
\hline $1999-00$ & $7,81,179$ & $9,03,614$ & 1156 \\
\hline $2000-01$ & $7,16,650$ & $2,74,815$ & 383 \\
\hline $2001-02$ & $8,14,607$ & $9,08,795$ & 4116 \\
\hline $2002-03$ & $7,77,473$ & $3,63,020$ & 467 \\
\hline $2003-04$ & $7,49,791$ & $2,78,604$ & 372 \\
\hline $2004-05$ & $6,85,995$ & $2,07,681$ & 303 \\
\hline $2005-06$ & $8,72,000$ & $7,06,000$ & 809 \\
\hline $2006-07$ & $8,99,035$ & $3,91,965$ & 335 \\
\hline $2007-08$ & $8,91,202$ & $5,16,115$ & 579 \\
\hline $2008-09$ & 896826 & 1130126 & 1260 \\
\hline
\end{tabular}

Source: Directorate of Economics and Statistics India, Various issues.1996-2009

\section{Area, Production and Productivity of Groundnut at National Level to District Level}

Table 5 presents the comparative analysis of area, production and productivity of groundnut crop at National level, state level and at district level during 2005-2006. The area under groundnut production was 75, 96,000 hectares in India during 2005-2006. During the same year, the area under groundnut in Andhra Pradesh was 21,98,000 hectares (28.94 percent) and 7,59,000 hectares in Anantapuram district with a share of 9.99 percent of India's total groundnut area and 34.53 percent of Andhra Pradesh total groundnut area during 20052006.

Table 5: Area, Production and Yield at National, State and at the District Level during 1996-2006 (Area 000'hectares, Production in 000' tons)

\begin{tabular}{|c|c|c|c|c|c|c|c|}
\hline Year & & India & $\begin{array}{c}\text { Growth } \\
\text { Rate }\end{array}$ & $\begin{array}{l}\text { Andhra } \\
\text { Pradesh }\end{array}$ & $\begin{array}{c}\text { Growth } \\
\text { Rate }\end{array}$ & Anantapuram & $\begin{array}{c}\text { Growth } \\
\text { Rate }\end{array}$ \\
\hline \multirow{3}{*}{$1996-97$} & Area & 7596 & 0.96 & 2198 & -0.99 & 759 & 2.02 \\
\hline & Production & 8643 & 14.04 & 2044 & -22.13 & 555 & -43.82 \\
\hline & Yield & 1138 & 13.01 & 630 & -32.26 & 731 & -44.95 \\
\hline \multirow{3}{*}{$1997-98$} & Area & 7088 & -6.69 & 1834 & -16.56 & 671 & -11.59 \\
\hline & Production & 7370 & -14.73 & 1156 & -43.44 & 250 & -54.95 \\
\hline & Yield & 1040 & -8.61 & 1031 & 63.65 & 372 & -49.11 \\
\hline \multirow{3}{*}{ 1998-99 } & Area & 7396 & 4.34 & 1992 & 8.61 & 781 & 16.39 \\
\hline & Production & 8982 & 21.87 & 2155 & 86.42 & 904 & 261.6 \\
\hline & Yield & 1214 & 16.73 & 606 & -41.22 & 1156 & 211.02 \\
\hline \multirow{3}{*}{ 1999-00 } & Area & 6867 & -7.15 & 1795 & -9.89 & 815 & 4.35 \\
\hline & Production & 5258 & -41.46 & 1089 & -49.47 & 909 & 0.55 \\
\hline & Yield & 766 & 26.4 & 607 & 0.16 & 1115 & -3.63 \\
\hline \multirow{3}{*}{ 2000-01 } & Area & 6733 & -1.95 & 1865 & 3.4 & 777 & -4.54 \\
\hline & Production & 6410 & 21.9 & 2035 & 86.86 & 363 & -60.02 \\
\hline & Yield & 952 & 24.28 & 1091 & 79.74 & 467 & -58.12 \\
\hline
\end{tabular}




\begin{tabular}{|c|c|c|c|c|c|c|c|}
\hline \multirow{3}{*}{ 2001-02 } & Area & 6240 & -7.32 & 1691 & -9.32 & 749 & -3.73 \\
\hline & Production & 7027 & 9.63 & 1250 & -38.57 & 279 & -23.41 \\
\hline & Yield & 1126 & 18.28 & 739 & -32.26 & 372 & -20.34 \\
\hline \multirow{3}{*}{$2002-03$} & Area & 5953 & 6.17 & 1470 & -13.07 & 686 & -8.41 \\
\hline & Production & 4121 & 44.46 & 821 & -34.32 & 208 & -25.45 \\
\hline & Yield & 694 & -38.36 & 558 & -24.49 & 302 & -18.82 \\
\hline \multirow{3}{*}{ 2003-04 } & Area & 5998 & 0.75 & 1493 & 1.56 & 686 & 0 \\
\hline & Production & 8127 & 97.21 & 986 & 20.1 & 208 & 0 \\
\hline & Yield & 1355 & 95.24 & 660 & 18.3 & 302 & 0 \\
\hline \multirow{3}{*}{ 2004-05 } & Area & 6827 & -13.82 & 1841 & 23.31 & 872 & 27.11 \\
\hline & Production & 6774 & -16.65 & 1639 & 66.23 & 706 & 239 \\
\hline & Yield & 992 & -26.79 & 890 & 34.85 & 809 & 168 \\
\hline \multirow{3}{*}{$2005-06$} & Area & 6853 & 0.38 & 1876 & 1.9 & 899 & 3.09 \\
\hline & Production & 7867 & 16.13 & 1366 & -16.66 & 391 & -44.62 \\
\hline & Yield & 1148 & 15.72 & 728 & -18.2 & 435 & -46.23 \\
\hline
\end{tabular}

Source: Directorate of Economics and Statistics India, Various issues.2006

The production of groundnut during the same period in was 86,43,000 tons in India, 20,44,000 tons in Andhra Pradesh (23.65 percent) and 5,55,000 tons in Anantapuram district (6.42 percent of India's production and 27.15 percent of A.P.). The area under groundnut in India was declined to 7396 thousand hectares in 199899 but the production was increased to 89, 82,000 tons during the same year in India. The yield of groundnut per hectare was $1,137 \mathrm{kgs}$ in India, $630 \mathrm{kgs}$ in Andhra Pradesh and $731 \mathrm{kgs}$ in Anantapuram district. The area under groundnut in India fluctuated between 75,96,000 hectares in 1996-97 and 59,53,000 hectares in 2002-03.

In Andhra Pradesh, the area under groundnut was also fluctuated from year to year. The growth rate of area under groundnut in India was in negative trend in five out of ten years under study. In Andhra Pradesh the growth rate was negative in four out of ten years under reference. Whereas in Anantapuram district the growth rate of area under groundnut during 1996-97 to 2005-2006 was negative in four out of ten years under study. Regarding to the growth rate of production trends in India, A.P. and same in Anantapuram district was also negative in some years under study. The reason for this may be due to low rainfall under reference at national level to the district level.

The productivity of groundnut in India varied between 1,355 kgs in 2003-2004 and $694 \mathrm{kgs}$ in 2002-03. Regarding to the state of Andhra Pradesh the yield per hectare was fluctuated between 1,091 kgs in 2000-01 and $558 \mathrm{kgs}$ per hectare in 2002-03. In Anantapuram district the yield per hectare was high (1,156 kgs per hectare), in 1998-99 and low in 2002-03 and 2003-04 (302 kgs per hectare).

\section{Comparative Statement Of Groundnut Production}

The table 6 shows the comparative analysis of groundnut production in Andhra Pradesh and in Anantapuram district during 1996-97 to 2005-2006. The production of groundnut in Andhra Pradesh was 21,55,067 tons in 1998-99 (highest production during the decade) and 8,20,654 tons (low production) in 200022003. Whereas in Anantapuram district the production of groundnut was high during 2000-01 $(9,08,795)$ and low during 2003-04 (2,07,681 tons). The share of groundnut production in Anantapuram district to the total groundnut production of Andhra Pradesh varied from 21.07 percent in 2003-04 to 43.06 percent during 2004-05.

Table 6: Comparative Statement of Groundnut Production in Andhra Pradesh State and in Anantapuram District 1996-2006 (in tons)

\begin{tabular}{|c|c|c|c|}
\hline Year & Andhra Pradesh & Anantapur & Percentage 3/2 \\
\hline $1996-97$ & 2044971 & 555251 & 27.15 \\
\hline $1997-98$ & 1155930 & 250175 & 21.64 \\
\hline $1998-99$ & 2155067 & 903614 & 41.93 \\
\hline $1999-00$ & 1089246 & 274815 & 25.23 \\
\hline $2000-01$ & 2142953 & 908795 & 42.41 \\
\hline $2001-02$ & 1250233 & 363020 & 29.04 \\
\hline $2002-03$ & 820654 & 278604 & 21.07 \\
\hline $2003-04$ & 985813 & 207681 & 43.06 \\
\hline $2004-05$ & 1639241 & 706000 & 28.69 \\
\hline $2005-06$ & 1365817 & 391965 & 43.32 \\
\hline $2006-07$ & 742637 & 321768 & 43.41 \\
\hline $2007-08$ & 2602847 & 1130126 & 1028 \\
\hline $2008-09$ & 973264 & 100012 & \\
\hline
\end{tabular}

Source: Directorate of Economics and Statistics, Andhra Pradesh. 


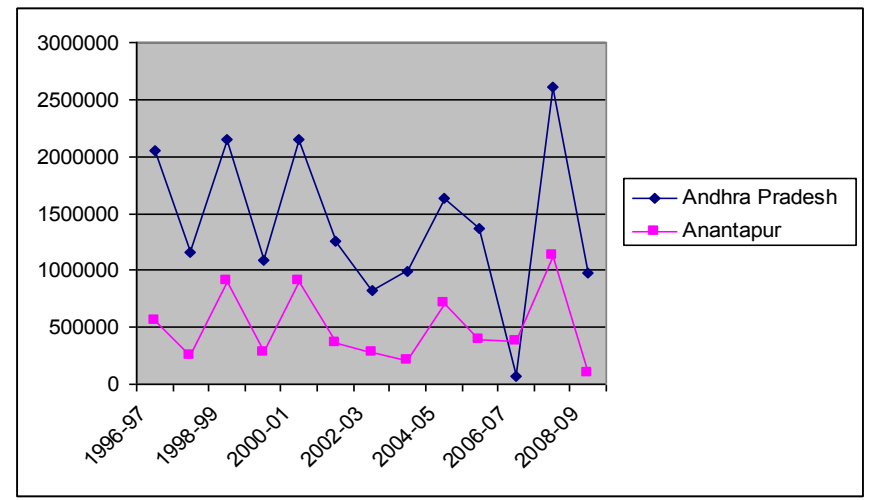

Fig. 4: Production of Groundnut in Andhra Pradesh and Anantapuram District

The diagram 4 represents the production of groundnut in Andhra Pradesh and in Anantapuram district during the decade under study. In the state of Andhra Pradesh as a whole, the area under groundnut was also fluctuated from year to year. The growth rate of area under groundnut in India was in negative trend in five out of ten years under study. In Andhra Pradesh the growth rate was negative in four out of ten years. Whereas in Anantapuram district the growth rate of area under groundnut during 1996-97 to 2005-2006 was negative in four out of ten years.

\section{Conclusions}

Groundnut is the most important oilseed crop in India. Especially in drought prone district of Anantapuram, the farmers are mainly depends on groundnut cultivation. Due to lack of irrigation facilities and poor alternative cropping pattern in rain fed areas like Anantapuram and in other Rayalaseema districts the farmers have been cultivating groundnut crop from the last several decades. But of nine oil seed crops grown in India, the area under groundnut accounts for about 45 percent of the total cropped area and 55 percent of the total oilseeds area.

India is the major groundnut producing country in the world. It stands third place in exporting of groundnut and earned an amount of Rs. 52,579 lakhs during 2005-2006. The area under groundnut in India varied from 59,53,000 tons in 2002-03 to 75,96,000 tonnes in 1996-97 and its production varied from 46,63,000 tons to $89,82,000$ tons during the decade under study. On an average the yield per hectare in India was 1048.80 kgs.

Among the major groundnut producing states of India Gujarat stands first place in area and production of groundnut followed by Andhra Pradesh. The yield per hectare was high in Tamil Nadu followed by Rajasthan. In Andhra Pradesh the annual average production of groundnut during the decade under study was 1464992.50 tons and the annual average yield per hectare was $796.50 \mathrm{kgs}$. The area and production of groundnut was high in Rayalaseema districts comparatively other regions of the state.

In Anantapuram district of Rayalaseema region in Andhra Pradesh the annual average production of groundnut crop during 1996-97 to 2008-09 was 100012 tons and annual average yield per hectare during the same period was $604.40 \mathrm{kgs}$.

\section{References}

[1] Kalamkar, S.S., (2006), Prospects of Contract Farming in India in the Context of Globalisation, Indian Journal of Agricultural Marketing, Vol, 20, No, 3, September-December, p.25.

[2] GOI (2008) Economic Survey of India 2008, Government of India, New Delhi.

[3] Patel, G.N., and N.L. Agarwal, (1993), Price Behaviour of Groundnut in Gujarat”, Indian Journal of Marketing, Vol.7, No.2, JulyDecember, p.144.

[4] Pant, D.C. and Pradeep Pal, (2004), Comparative Economics of Agro-processing units for Groundnut in Southern Rajasthan, Indian Journal of Agricultural Marketing, Vol, 18, No.1, January-April, p.50-57.

[5] Margaret Digly and Gretton, R.H. (1965), Cooperative Marketing for Agricultural Products, Agricultural Development, Paper No.53, FAO; (Rome Food and Agricultural Organisation, pp. 5-17. 